\title{
Reconsidering Our Investments: A Commentary on Gut-Brain Health
}

Tousignant $\mathbf{O H}^{*}$

Department of Clinical Psychology, Suffolk University, Boston, MA, USA

*Corresponding author: Olivia H Tousignant, M.S., Ph.D. Student, Department of Clinical Psychology, Suffolk University, 73 Tremont Street \#8, Boston, MA 02108, USA, Tel: 617 573-8293; E-mail: ohtousignant@gmail.com

Rec date: February 10, 2018; Acc date: March 12, 2018; Pub date: March 15, 2018

Copyright: (c) 2018 Tousignant $\mathrm{OH}$. This is an open-access article distributed under the terms of the creative commons attribution license, which permits unrestricted use, distribution, and reproduction in any medium, provided the original author and source are credited.

\begin{abstract}
Low gut microbial diversity is linked to increased symptoms of psychopathology. Genetic and molecular research reveals the importance of diversifying and nourishing the bacteria in the microbiome to promote mental health through the gut-brain axis, yet threat to human microbial health continues to exist in industrialized regions. While adults may consent to the consequences of poor gut health, children do not have that option. This commentary presents the viewpoint that, to thrive as a species, humans must invest in the gut health of children. Strategic ways of investing are discussed.
\end{abstract}

\section{Commentary}

A smiling child eats breakfast and afterward is overcome with agitation and anger. A cheerful student eats lunch and later experiences nervousness and crying spells. A bright youngster eats a snack and loses focus during school. Surely, these cognitive and emotional responses are characteristic of many children, but what contributes to their intensity and frequency? Increasing evidence indicates that gut health is inextricably linked to emotional and mental well-being [1-3]. Unfortunately, many individuals are not aware of this research and/or do not have access to important nutritional resources. The purpose of this commentary is to advocate for children's emotional well-being by way of microbial diversity. While adults may consent to the consequences of poor gut health, children do not have that option. As adults, it is our responsibility to protect all children from this internal pollution.

There are trillions of bacteria in the healthy human gut (also known as the gastrointestinal tract). These bacteria constitute the microbiome, an ecosystem that contains approximately 90 percent of our cells and helps create neurotransmitters essential for positive mood stabilization and stress management. A diverse microbiome is vital for our survival and begins developing in the womb [4]. By the age of three, the healthy human has developed a gut microbial ecosystem resembling an adult's in its ability to facilitate healing, resilience, and well-being [5]. The bad news is that most of the food we serve to children, especially at school, is harmful to the gut; the good news is that guts are extremely resilient.

People living in industrialized regions tend to have poor gut health largely because our bodies were designed to be fueled by earth's nutrients rather than by processed products. Regularly, people consume infinite combinations of neurotoxins including hybridized and artificially concocted food full of hormones, antibiotics, pesticides, dyes, sugars, and preservatives. When ingested, these unnatural substances make the gastrointestinal walls porous, leak into the bloodstream, glide past the blood-brain barrier, and poison the brain.

Fortunately, people can repair their guts by consuming probiotics and prebiotics. Probiotics are live bacteria that replenish the microbiome and can be found in fermented food and drinks such as sauerkraut, kimchi, yogurt, kefir, and kombucha. Prebiotics nourish the bacteria in the microbiome and can be found in onions, garlic, radishes, and more. (Organic is always better since pesticides harm the gut) $[6,7]$. A thriving microbiome is a requisite for mental and emotional wellbeing.

Studies examining relationships between the gut and psychological variables have found that repairing the gut attenuates the stress response [8] and reduces symptoms of autism [9-11], anxiety and depression [12-16], bipolar disorder [17], eating disorders [18], and schizophrenia $[19,20]$. Although promoting gut health may not be the prerogative of all healthcare providers, many do promote patients' health via gut repair [21]; however, larger systemic barriers seem to halt our daily attempts to nourish children. Aiming to include all people in this transformation, we must continue to establish financial and logistical infrastructure that will support people who lack resources to initiate this change. Collectively, we need to advocate for the health of all children to facilitate healing, resilience, and well-being for future generations.

A major systemic improvement could occur through school meal programs, which largely ignore the science of gut and brain health. Ironically, in an environment where children go to learn, children's brains are becoming increasingly malnourished. In 2016, Congress enacted the Improving Child Nutrition and Education Act, which states that schools must meet "minimum nutritional requirements" prescribed by the Secretary based on "tested nutrition research." Although this policy seems to promote increased child well-being, it is not likely to facilitate optimal health if Congress members are strategically selective in the literature they consult. For example, the bill outlines a need to increase "milk consumption in schools in a manner consistent with the number of servings recommended under such Dietary Guidelines." While there is a lack of transparency about what research and which funding agencies support the Dietary Guidelines, there is also evidence indicating that cow milk contributes to gut leakiness and an increasingly early onset of puberty $[22,23]$. Let us continue to search for loopholes and advocate for change; children need us to invest in them.

As a continuously evolving species, it is our duty to help future generations thrive and to acknowledge this paramount branch of research for understanding psychiatric disorders [24]. For too long, 
Citation: Tousignant $\mathrm{OH}$ (2018) Reconsidering Our Investments: A Commentary on Gut-Brain Health . J Mol Genet Med 12: 335 . doi: $10.4172 / 1747-0862.1000335$

Page 2 of 2

food corporations have shaped human behavior so that people excuse their consumption of neurotoxins for the sake of companies' profits and immediate gratification [25]. Might children deserve better? Akin to how we teach children that brushing their teeth before bed and sleeping through the night is good for their health, it is our responsibility to inform them that nourishing the gut is a valuable and essential component to living a high quality, long life.

\section{References}

1. Collins SM, Surette M, Bercik P (2012) The interplay between the intestinal microbiota and the brain. Nature Rev Microbiol 10: 735-742.

2. Dinan TG, Cryan JF (2017) Microbes, immunity, and behavior: Psychoneuroimmunology meets the microbiome. Neuropsychopharmacol 42: 178-192.

3. Liu RT (2017) Microbiome as a novel paradigm in studying stress and mental health. Am Psychol 72: 655-667.

4. Cong X, Xu W, Romisher R, Poveda S, Forte S, et al. (2016) Gut microbiome and infant health: Brain-Gut-Microbiota axis and host genetic factors. Yale J Biol Med 89: 299-308.

5. Yatsunenko T, Rey FE, Manary MJ, Trehan I, Dominguez-Bello MG, et al. (2012) Human gut microbiome viewed across age and geography. Nature 486: 222-227.

6. Curl CL, Fenske RA, Elgethun K (2003) Organophosphorus pesticide exposure of urban and suburban preschool children with organic and conventional diets. Environ Health Perspec 115: 377-382.

7. Roberts EM, English PB, Grether JK, Windham GC, Somberg L, et al. (2007) Maternal residence near agricultural pesticide applications and autism spectrum disorders among children in the California Central Valley. Environ Health Perspec 115: 1482-1489.

8. Ait-Belgnaoui, Durand H, Cartier C, Chaumaz G, Eutamene H, et al. (2012) Prevention of gut leakiness by a probiotic treatment leads to attenuated HPA response to an acute psychology stress in rats. Psychoneuroendocrinol 37: 1885-1895.

9. Knivsberg AM, Reichelt KL, Hoien T, Nodland M (2002) A randomised, controlled study of dietary intervention in autistic syndromes. Nutritional Neurosci 5: 251-261.

10. Needham BD, Tang W, Wu W (2018) Searching for the gut microbial contributing factors to social behavior in rodent models of autism spectrum disorder. Dev Neurobiol 1: 1-2.

11. Parracho HM, Gibson GR, Knott F, Bosscher D, Kleerebezem M, et al. (2010) A double-blind, placebo-controlled, crossover-designed probiotic feeding study in children diagnosed with autism spectrum disorders. Intern J Probiotics Prebiotics 5: 69-74.

12. Akkasheh G, Kashani-Poor Z, Tajabadi-Ebrahimi, Jafari P, Akbari H, et al. (2015) Clinical and metabolic response to probiotic administration in patients with major depressive disorder: A randomized, double-blind, placebocontrolled trial. Nutrition 32: 315-320.

13. Crumeyrolle-Arias M, Jaglin M, Bruneau A, Vancassel S, Cardona, A, et al. (2014) Absence of gut microbiota enhances anxiety-like behavior and neuroendocrine response to acute stress in rats. Psychoneuroendocrinol 42: 207-217.

14. Hoban AE, Stilling RM, Moloney GM, Moloney RD, Shanahan F, et al. (2017) Microbial regulation of microRNA expression in the amygdala and prefrontal cortex. Microbiome 5: 1-11.

15. Slyepchenko A, Carvalho AF, Cha DS, Kasper S, McIntyre RS (2014) Gut emotions-Mechanisms of action of probiotics as novel therapeutic targets for depression and anxiety disorders. CNS Neurol Disord 13: 1770-1786.

16. Yu M, Jia H, Zhou C, Yang Y, Zhao Y, et al. (2017) Variations in gut microbiota and fecal metabolic phenotype associated with depression by 16s rRNA gene sequencing and LC/MS-based metabolomics. J Pharma Biomed Anal 138: 231-239.

17. Evans SJ, Bassis CM, Hein R, Assari S, Flowers SA, et al. (2017) The gut microbiome composition associates with bipolar disorder and illness severity. J Psych Res 87: 23-29.

18. Kleiman SC, Watson HJ, Bulik-Sullivan EC, Huh EY, Tarantino LM, et al. (2015) The intestinal microbiota in acute anorexia nervosa and during renourishment: Relationship to depression, anxiety, and eating disorder psychopathology. Psycho Med 77: 969-981.

19. Dickerson FB, Stallings C, Origoni A, Katsafanas E, Savage CL, et al. (2014) Effect of probiotic supplementation on schizophrenia symptoms and association with gastrointestinal functioning: A randomized, placebo-controlled trial. Primary Care Cocmpanion CNS Disord 16: $1-20$.

20. Fellerhoff B, Wank R (2009) Transporter associated with antigen processing and the chaperone tapasin: Are non-classical HLA genes keys to the pathogenesis of schizophrenia? Med Hypoths 72: 535-538.

21. Hyman M (2009) The ultramind solution: Fix your broken brain by healing your body first. Scribner, New York, USA.

22. Isolauri E, Majamaa H, Arvola T, Rantala I, Virtanen E, et al. (1993) Lactobacillus casei strain GG reverses increased intestinal permeability induced by cow milk in suckling rats. Gastroenterol 105: 1643-1650.

23. Rich-Edwards JW, Ganmaa D, Pollak MN, Nakamoto EK, Kleinman K, et al. (2007) Milk consumption and the prepubertal somatotropic axis. Nutrition J 6: 1-8.

24. Anglin R, Surrette M, Moayyedi P, Bercik P (2015) Lost in translation: The gut microbiota in psychiatric illness. Canadian J Psychiat 60: 460-463.

25. Chopra M, Darnton-Hill I (2004) Tobacco and obesity epidemics: Not so different after all? British Med J 328: 1558-1560. 